\title{
Graves' disease presenting as paranoid schizophrenia in a Nigerian woman: a case report Okechukwu S Ogah ${ }^{1}$, Anne O Timeyin ${ }^{1}$, Oluyinka A Kayode ${ }^{1}$, Adedeji S Otukoya ${ }^{1}$, Rufus O Akinyemi ${ }^{1}$ and Folashade I Adeyemi ${ }^{2}$
}

\author{
Addresses: ${ }^{1}$ Department of Medicine, Federal Medical Centre, PMB 3031 Sapon, Abeokuta, Ogun State, Nigeria \\ ${ }^{2}$ Department of Psychiatry, Federal Medical Centre, PMB 3031 Sapon, Abeokuta, Ogun State, Nigeria \\ Email: OSO* - osogah56156@yahoo.com; AOT - kemitimeyin@yahoo.com; OAK - easydoc@yahoo.com; ASO - dejiotukoya@yahoo.com; \\ ROA - rufusakinyemi@yahoo.com; FIA - folashadeadeyemi@yahoo.com \\ * Corresponding author
}

Received: 21 March 2009 Accepted: 29 July 2009 Published: 10 August 2009

Cases Journal 2009, 2:6708 doi: 10.4076/1757-1626-2-6708

This article is available from: http://casesjournal.com/casesjournal/article/view/6708

(C) 2009 Ogah et al..; licensee Cases Network Ltd.

This is an Open Access article distributed under the terms of the Creative Commons Attribution License (http://creativecommons.org/licenses/by/3.0),

which permits unrestricted use, distribution, and reproduction in any medium, provided the original work is properly cited.

\begin{abstract}
Paranoid syndromes in Graves' disease are rare. The true incidence is lacking. Most reports have emanated from developed countries where medical investigations are readily available. No report of such has emanated from Nigeria. We report a 43-year-old female Nigerian with Graves' disease associated with paranoid schizophrenia and review the literature.
\end{abstract}

\section{Introduction}

More than a century ago, Basedow first described psychiatric illness (most probably mania) in a patient with Grave's disease [1]. Since then several anecdotal case reports of psychiatric manifestations of hyperthyroidism have been reported [2-4]. However most medical textbooks do not mention psychosis as a presenting feature of hyperthyroidism. On the other hand psychosis associated with hypothyroidism is universally documented $[5,6]$.

Paranoid syndromes in Graves' disease are rare. The true incidence is lacking. Most reports have emanated from developed countries where medical investigations are readily available. To the best of our knowledge, the only attempt to report on psychiatric features of hyperthyroidism (in stable state) in Nigeria was by Kolawole et al. [7] where he reported two cases of mild depression out of the eight patients studied.
We report a 43-year-old female Nigerian with Graves' disease associated with paranoid schizophrenia.

\section{Case presentation}

A 43-year-old female Nigerian was referred to us from a nearby psychiatric hospital where she was hospitalized for four weeks on account of an eight months history of violent behavior, accusing her mother of being a witch, and 2 months history of keeping to self, poor sleep, talking and laughing to self, threatening to harm neighbours, poor personal hygiene and weight loss.

She was living in the UK prior to the onset of illness but often visited her relations in Nigeria from time to time. In November 2006, she had arrived in Nigeria unexpectedly, calling her mother from the airport and abusing her, calling her a witch. She accused her mother of stealing her property and that she had come to take them back. From 
then on, she was observed to be increasingly suspicious of her mother, and would not interact with other members of the family. She was also observed to be sleeping poorly, talking and laughing to self, and neglecting her personal hygiene. She moved out of the house to another apartment in the compound where she stayed alone and was often observed to be praying excessively. She accused her neighbours of wanting to harm her and then bought a cutlass, threatening to attack anyone who came near her. She resisted initial attempts to bring her to hospital.

There was no history of fever or head injury prior to onset of illness. No history of weepy spells, or feelings of worthlessness, hopelessness, loss of interest in previously enjoyable things, guilt feelings or suicidal ideation. No history of extravagant spending but at least on one occasion during this episode she was observed to be giving out some of her belongings without obvious reasons.

She was managed as paranoid schizophrenia and was placed on antipsychotic medications. Rather than improving, her condition worsened which necessitated a search for an organic cause of her illness. On discovery, that patient also had features of hyperthyroidism she was referred to us for medical treatment. She had noticed anterior neck swelling 30 months earlier in the UK and was placed on iodized salt by her general practitioner.

The neck swelling has been increasing in size. There was associated history of palpitations, excessive sweating, and tremulousness. Her friends had drawn her attention to protrusion of her eyes but can not recall when exactly. She also noticed increased pigmentation of her skin. There has been significant weight loss despite increased appetite. No associated passage of frequent loose stools. No history of change in the quality of the voice, difficulty in breathing or swallowing and neck pain.

Patient returned to Nigeria from the UK where she lived for 11 years about 8 months prior to presentation with the aim of setting up a small scale business. She had no past or family history of psychotic behavior. Prior to her return to Nigeria, she had worked as a social worker in the UK. She has no family history of psychiatric illness.

Clinical examination revealed a chronically ill - looking woman with staring gaze, lid lag, lid retraction and was mildly pale. She had tremors on the outstretched hand as well as increased pigmentation of the skin.

The anterior neck swelling, measured about 6 by $8 \mathrm{~cm}$, moved with swallowing but not with protrusion of the tongue, firm to hard in consistency, with a smooth surface, no retrosternal extension present, no palpable regional lymph nodes present and no bruits were heard.
The central nervous system examination revealed a conscious agitated woman. Her speech was irrelevant, was deluded and had no insight.

The initial mental state examination showed that she was poorly groomed and restless. She was irritable and threatening as well as talkative and abusive. Her speech was irrational, with flight of ideas. There were persecutory delusions towards relatives, especially her mother. The patient was very uncooperative and had no insight.

She had a pulse of 120 beats/minute; blood pressure of $120 / 70 \mathrm{mmHg}$. The apex beat was not displaced and the heart sounds were normal. Chest and abdominal examination did not reveal any abnormality.

Thyroid function tests done before patient was referred to our centre showed: $\mathrm{T}-330.9 \mathrm{ng} / \mathrm{dL}$ (Normal = 69-202 ng/ $\mathrm{dl}), \mathrm{T} 4-261.6 \mathrm{nmol} / \mathrm{L}$ (Normal $-58.7-103 \mathrm{nmol} / \mathrm{l}$ ) and TSH $-0.12 \mathrm{microIU} / \mathrm{L}(\mathrm{Normal}=0.32-5.2 \mathrm{microIU} / \mathrm{L})$.

A repeat thyroid function carried out after weeks on antithyroid drugs revealed T3 - $2.1 \mathrm{ng} / \mathrm{ml}(0.8-2.0)$, $\mathrm{T} 4$ - $163 \mathrm{ng} / \mathrm{ml}$ (45-115), TSH - 0.1 microIU/ml (0.54-3.7) and anti thyroid antibody value - $69.5 \mathrm{IU} / \mathrm{mL}$ (3.5-7.6). Thyroid ultrasound scan done showed a multinodular goitre. Patient had a Packed Cell Volume of 26\%; Total white cell count was $3.5 \times 10 / \mathrm{L}^{9}$, (differentials Neutrophils $30 \%$, lymphocytes $66 \%$, monocytes $4 \%$, basophils $0 \%$, eosinophils $0 \%$ ). Platelet count was $160,000 / \mathrm{L}$. Blood film showed the presence of hypochromic erythrocytes, relative lymphocytosis. Erythrocyte sedimentation rate was $28 \mathrm{~mm} / \mathrm{hr}$ (westergreen).

Patient was admitted and placed on oral propranolol $40 \mathrm{mg}$ thrice daily, oral carbimazole $10 \mathrm{mg}$ thrice daily, oral Chlorpromazine $200 \mathrm{mg}$ twice daily and oral artane 5 mg daily.

She was initially placed on oral Haloperidol $15 \mathrm{mg}$ daily in divided doses, with intramuscular chlorpromazine given prn for severe agitation at the psychiatric hospital. When there was no significant reduction in her level of agitation after a week on these medications, haloperidol was discontinued and oral chlorpromazine commenced.

During the first few days on admission, she was aggressive, restless, hallucinated and sometimes trying to attack other patients which necessitated four point restrain for few days. Additional therapy includes oral dexamethsone $4 \mathrm{mg}$ twice daily.

Over the next few days she became calm, well oriented but exhibited swinging mood (but in most of the time showed 
features of mania) and was gradually weaned off antipsychotics.

She responded well to anti-thyroid drugs. Within eight weeks she became euthyroid. On follow-up (over 12 months now), she has remained symptom free and has since returned to her work and there has not been recurrence of psychiatric symptoms.

\section{Discussion}

The case presented is remarkable in that psychotic symptoms are uncommon in Graves' disease and usually occur in the thyrotoxic state $[1,8]$. Even in this situation, the association of paranoid schizophrenia is still controversial [9].

Common psychiatric syndromes in hyperthyroidism are anxiety and mood disturbances. The thyroid hormone is said to influence the functioning of the brain and can interact with mood regulation through targets in specific brain connections $[10,11]$. The paranoid schizophrenia in this case must have been due to thyrotoxicosis since it could not be attributed to any other organic conditions in the patient. More so her clinical symptoms did not improve with antipsychotic therapy she received for 4-weeks at the psychiatric hospital. There was also no history of ingestion of exogenous thyroid preparations although facilities were not available for Technecium-99 m pyrophosphate thyroid scan.

She was offered subtotal thyroidectomy but she declined. Complete resolution of psychosis has been reported with any of these treatments supporting the assumption that the causal relationship between Graves' disease and organic psychosis [8]. The mechanism for this is still unclear. One school of thought believes that fall in antithyroid antibody may be responsible.

\section{Conclusion}

Hyperthyroidism can present with many psychiatric syndromes including paranoid schizophrenia. A high sense of suspicion is often required to detect the association.

\section{Consent}

Written informed consent was obtained from the patient for publication of this case report. A copy of the written consent is available for review by the Editor-in-Chief of this journal.

\section{Competing interests}

The authors declare that they have no competing interests.

\section{Author's contributions}

OSO, AOT, OAK, ASO, ROF, and FIA made substantial contribution to concept this case report. All authors read and approved the final manuscript.

\section{References}

I. Greer S, Parsons V: Schizophrenia-like psychosis in thyroid crisis. Br J Psychiatry 1968, I | 4: 1357-| 362

2. Jadresic DP: Psychiatric aspects of hyperthyroidism. J Psychosom Res 1990, 34:603-615.

3. Knezevic A, Todorovic-Dilas L, Vukic-Drezgic S: Psychological and possible psychiatric aspects of hyperthyroidism. Med Pregl 1989, 42:438-440.

4. Harrer G: Neuro-psychiatric aspects of hyperthyroidism. Wien Med Wochenschr 197I, I 21:662-664.

5. Asher R: Crises in myxoedema. Br Med J 1955, I:47| I-473.

6. Asher RA: Myxoedema. Med Illus 195I, 5:388-394.

7. Kolawole BA, Ikem RT: A study of psychiatric symptoms in thyrotoxic Nigerians. Afr J Med Med Sci 2003, 32:33-35.

8. Lazarus A, Jaffe R: Resolution of thyroid-induced schizophreniform disorder following subtotal thyroidectomy: case report. Gen Hosp Psychiatry I986, 8:29-31.

9. Steinberg PI: A case of paranoid disorder associated with hyperthyroidism. Can J Psychiatry 1994, 39:153-156.

10. Kirkegaard C, Faber J: The role of thyroid hormones in depression. Eur J Endocrinol 1998, 138:1-9.

II. Bauer M, Heinz A, Whybrow PC: Thyroid hormones, serotonin and mood: of synergy and significance in the adult brain. Mol Psychiatry 2002, 7:140-456.

\section{Do you have a case to share?}

\section{Submit your case report today}

- Rapid peer review

- Fast publication

- PubMed indexing

- Inclusion in Cases Database

\section{Any patient, any case, can teach us something}

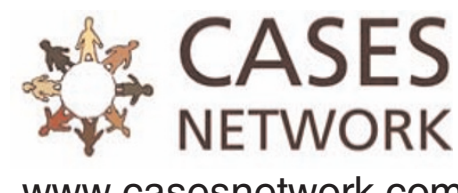

